\title{
Early fattening and improving feeding quality of Kejobong goats could reduce methane production and improve meat production
}

\author{
V. Restitrisnani, E. Pangestu, E. Rianto, M. Kurihara ${ }^{1}$, \\ F. Nabila, R. Adiwinarti, and A. Purnomoadi* \\ Faculty of Animal and Agricultural Sciences, Diponegoro University, Semarang 50275, Indonesia \\ ${ }^{1}$ National Institute of Livestock and Grassland Science, \\ The National Agriculture and Food Research Organization, Japan \\ *Corresponding Email: agung194@yahoo.com
}

Received October 04, 2021; Accepted December 23, 2021

\begin{abstract}
An experimental study was carried out to evaluate the implication of early fattening of Kejobong goats by improving feeding quality on methane production and meat production. Sixteen goats (8 young and 8 mature) were raised for 4 months study period. Nested design was used in this study, with young and mature as a nest factor, and diet (G7C3: 70\% grass and 30\% concentrate and $\mathrm{G} 3 \mathrm{C} 7: 30 \%$ grass and $70 \%$ concentrate) as the treatments. The main parameters observed were DMI, BWG, carcass (CWG) and meat weight gain (MWG), and methane emission. The results showed, the young goat fed G3C7 was higher than that fed G7C3 in DMI. The BWG's of goats fed G3C7 were higher than those fed G7C3, but there was no difference between ages in BWG. The FCR of young goat fed G3C7 was lower than that fed G7C3. The DMI of mature goat was higher than young goat, but there were no differences between the ages in DM digestibility, carcass weight and meat weight gain. The young and mature goats fed $\mathrm{G} 3 \mathrm{C} 7$ was significantly lower than that of $\mathrm{G} 7 \mathrm{C} 3$ in methane emissions per unit of BWG ( 0.28 vs 0.40 and 0.36 vs 0.53 , respectively), in methane emissions per unit CWG ( 0.60 vs 0.93 and 0.79 vs 1.47 , respectively), and methane emission per unit MWG (0.89 vs 1.42 and 1.16 vs 2.19, respectively). It can be concluded that fattening young Kejobong goats by improving feed quality is more environmentally friendly than fattening the mature ones.
\end{abstract}

Keywords: grass and concentrate ratio, young and mature goats, methane emission

\section{INTRODUCTION}

The world population was predicted to reach 9.7 billion by 2050 (UN, 2015; O’Mara, 2012), and it will increase global demand for livestock products about $70 \%$ or almost double in developing countries (FAO, 2009). This condition cannot be solved by increasing in livestock population due to the limitation of the global agricultural land area (O'Mara, 2012), and by the consideration that the livestock industry contrib- uted a significant amount of methane to global warming (Jiao et al., 2014; Gerber et al., 2013) that has a negative impact on feed utilization and livestock productivity (Makuvaro et al., 2018; Marino et al., 2016).

Many studies on reducing methane production from livestock while keeping animal production have been carried out for decades from manipulating rumen condition, increasing feed utilization, improving herd management including breed quality and it's related to a specific 
condition of the animal, to environmental impact as well as climate change (Zucalli et al., 2020; Marino et al., 2016; Waghorn and Hegarty, 2011). Environmental Protection Agency (EPA, 2005) recommended that improving livestock productivity, so that less methane is emitted per unit of product, is the most promising and costeffective technique for reducing emission is an applicable strategy in mitigating methane production. This has been proved by some studies in England and New Zealand that reported a reduction in GHG emission without a reduction in livestock population (Webb et al., 2014; Adler et al., 2013). The most applicable feeding method to achieve livestock production is by appropriate proportion among roughage and concentrate ratio (Chandramoni et al., 1999).

Another approach on mitigation in climate is Life Cycle Assessment (LCA) based on the flow of the entire production process (LEAP, 2014). By using this concept, the raw material in meat animal production is fattening animals and slaughters them at young ages. Therefore, the reduction on methane emission from meat animals could be achieved by early fattening method using young animal due to its accelerated growth (Wyngaard et al., 2018), and it must also consider on carcass and meat production (Nardone et al., 2010) which has an economic impact. Previous studies reported that early fattening on lamb could reduce 10 months raising period to obtain market body weight, reduce methane emissions for about 38\% (Purnomoadi, 2018), as well as $\mathrm{N}$ emissions for about $41 \%$ (Prima et al., 2019) compared to conventional raising system.

Goats are expected to be the future livestock, especially local goats. It is due to goats have a shorter rumen retention time than sheep and other ruminants (Tsiplakou et al., 2011), causing goats to be more efficient in utilizing feed for growth and produce less methane (Opio et al., 2013; Wang et al., 2016; Darcan and Silanikove, 2017; Teklebrhan et al., 2019). Therefore, goats are expected to be able to achieve high productivity and more responsive to mitigating global warming.

One of local goats in Indonesia is Kejobong goat (Lestari et al., 2018), that raised by farmers for meat production. The goat is generally fed merely with grass. When it gets mature, it is fattened by supplementing feed with concentrate at the amount of $30 \%$ of total diet. This study was aimed to evaluate the implication of early fatten- ing of Kejobong goats by improving feeding quality on meat production and methane emission.

\section{MATERIALS AND METHODS}

\section{Experimental Animal and Diet}

This study used 24 male Kejobong goats, consisted of 12 young (5 months old, $14.03 \pm$ $1.46 \mathrm{~kg}$ ) and 12 mature ( 9 months old, $22.32 \pm$ $1.99 \mathrm{~kg}$ ). Each four young and mature goats were slaughtered in the initial stage of the study as preliminary data of carcass and meat weight. Then, the other 16 heads of Kejobong goats $(8$ young and 8 mature) were raised for 4 months study period. The goats were placed in individual cage and the diets were formed into pellet given ad libitum as well as freshwater. Before the study, goats were dewormed to eliminate internal parasites. They fed diet consisted of tall grass (Panicum muticum) and concentrate which was composed from molasses (6\%) rice bran $(42 \%)$, soybean meal $(45 \%)$, cassava $(6 \%)$ and minerals $(1 \%)$.

\section{Experimental Design}

This study used nested experimental design, with age (young and mature Kejobong goats) as the nest factor and diet as the treatment. There were 2 diet treatments implemented, i.e. G7C3 (grass and concentrate ratio was 70:30) and G3C7 (grass and concentrate ratio was 30:70). The compositions of the feed ingredients and its composition are shown in Table 1. There were 4 treatment combinations, i.e. Y-G7C3 (young Kejobong goat fed $70 \%$ grass $+30 \%$ concentrate); Y-G3C7 (young Kejobong goat fed 30\% grass $+70 \%$ concentrate); M-G7C3 (mature Kejobong goat fed $70 \%$ grass $+30 \%$ concentrate); M-G3C7 (mature Kejobong goat fed $30 \%$ grass $+70 \%$ concentrate).

\section{Procedures}

The experiment was conducted in three periods, i.e. adaptation period (4 weeks), preliminary period (7 days) and data collection period (15 weeks), including 7 days digestion and metabolism trials and 3 days methane production measurements.

At the end of the experiments (week 15), the goats were slaughtered to obtain carcass and meat production after the data collection period. The slaughter method was done by following the halal method. The head and shank were severed 
Table 1. The ingredient and chemical composition of the diet (DM basis)

\begin{tabular}{lcc}
\hline & G7C3 & G3C7 \\
\hline Feed ingredients & $\ldots \ldots \ldots \ldots \ldots \ldots \ldots \ldots \ldots \ldots$ \\
Tall Grass (Panicum muticum) & $70 \ldots \ldots \ldots \ldots \ldots \ldots$ & $30 \ldots \ldots$ \\
Concentrate feed & 30 & 70 \\
Nutrient Composition & & \\
Dry Matter\# & 79.1 & 71.4 \\
Crude Protein & 10 & 14.7 \\
Ether Extract & 1.7 & 2.1 \\
Crude Fiber & 29.9 & 25.7 \\
Nitrogen Free Extracts & 46.7 & 44.8 \\
Ash & 11.7 & 12.7 \\
Total Digestible Nutrients\#\# & 64 & 69.7 \\
\hline \#D value is as Fed (\%); \#\# TDN value observed from digestion trials & &
\end{tabular}

and the carcass eviscerated by cutting around the vent to remove all the viscera. The empty carcass was weighted to obtain the carcass weight. The carcass was kept in a cooler for $5 \mathrm{~h}$ at $14^{\circ} \mathrm{C}$. The cold carcass was weighed and separated for meat, bones and fat.

\section{Parameters Measured}

Parameters measured in this study were dry matter intake (DMI), dry matter digestibility (DMD), digestible dry matter intake (DDMI), body weight gain (BWG), feed conversion ratio (FCR), carcass weight gain (CWG), meat weight gain (MWG), methane emission, methane emission/DMI, methane emission/BWG, methane emission/CWG, methane emission/ MWG. Dry matter intake was measured daily by weighing the feed given and the residuals. DM digestibility was measured by 7 -d total collection method in week 13. The DDMI was calculated by multiplying the DM digestibility to the DMI. Body weight was measured every week during the treatment period. BWG was calculated from the final body weight (BW) and the initial BW and then divided by the length of observation. FCR was calculated by dividing the DMI and BWG.

The carcass and meat percentage were calculated by dividing the carcass or meat weight by slaughter weight. The daily carcass weight gain (CWG) and meat weight gain (MWG) were obtained by calculating the difference between the weight of carcass and meat weight after being raised and the weight of carcass and meat of goat slaughtered at the beginning of the study, and then divided by the length of observation.

Methane emission was obtained using facemask method established by Kawashima et al. (2001) for two days in week 14. The mask was connected to a methane analyzer (Horiba Ltd., Japan) equipped with airflow meter to measure gas volume (Liter) to calculate total methane production. The data of methane emission was recorded automatically by IBM PC for 10 minutes at 3 hours intervals. The methane volume obtained was converted into gram units by conversion factor 1 liter of $\mathrm{CH}_{4}$ equals to $0.714 \mathrm{~g}$ (Brouwer, 1965).

\section{Statistical analysis}

The data obtained were analyzed using analysis of variance recommended by Gomez and Gomez (1984) using Microsoft Excel.

\section{RESULTS AND DISCUSSION}

\section{Feed Intake and Digestibility}

The young goat was significantly lower $(\mathrm{P}<0.01)$ than the mature goat in DMI (674 vs $908 \mathrm{~g} / \mathrm{d})$. The lower DMI of the young goat compared to the mature was attributed of fact that the body weight of the young goat $(17.6 \mathrm{~kg})$ was lower than that of the mature goat $(26.3 \mathrm{~kg})$. Body weight has consequence to the gut capacity of the animal, the bigger the animal the larger the gut capacity. This result was confirmed by previous studies (Fernandez et al., 2018; Dida et al., 
2019) that body weight is one of the factors that influence DMI. Feed intake is influenced by gut capacity, which in turn is a function of body weight. Animals of higher body weight have higher gut capacity, so that they are able to consume a higher amount of feed (Ali et al., 1990; Belanche et al., 2020).

However, when DMI was calculated in the percentage of body weight, the DMI of the young $(3.96 \%)$ was higher $(\mathrm{P}<0.05)$ than that of the mature goat $(3.53 \%)$. This phenomenon was addressed to the growth rate and metabolism rate of the young goat being higher than those of the mature goat, so that the young goat required more nutrients per body weight unit. This result was in agreement with the statement of Kearl (1982) that the young goat having 10-15 kg BW could consume $3.7 \% \mathrm{BW}$, while the mature goat of $20-25 \mathrm{~kg}$ BW could only consume $3.1 \%$ BW.

The DMI of diet G3C7 (767 g/d) was higher
$(\mathrm{P}<0.01)$ than that of diet G7C3 $(581 \mathrm{~g} / \mathrm{d})$ in the young goat. The higher DMI of diet G3C7 in the young goat can be attributed to the higher digestibility of this diets as compared to diet G7C3 (Table 2). Meanwhile, there was no significant difference $(\mathrm{P}>0.05)$ between diets in DMI of the mature goat (averaged $908 \mathrm{~g} / \mathrm{d}$ ). This may be attributed to fact that the growth rate of the mature goat had been slowing down and approaching its maximum cell capacity, so that the nutrient requirement was relatively low, resulting in a low feed intake. This, in turn, caused the different nutrient content between the diets not to affect DMI.

There was no significant difference $(\mathrm{P}>0.05)$ between ages of goat in DM digestibility (averaged 68.7\%). The similarity of DM digestibility in both ages of goats (Table 2) indicated that the digestive tract of the young had well developed, so that the young was able to digest the

Table 2. The effect of different age and feed quality on Kejobong goat's productivity

\begin{tabular}{|c|c|c|c|c|}
\hline \multirow{2}{*}{ Parameter } & \multirow{2}{*}{ Age of goat } & \multicolumn{2}{|c|}{ Diet } & \multirow{2}{*}{ Age average } \\
\hline & & G7C3 & G3C7 & \\
\hline \multirow[t]{2}{*}{ Dry matter intake, $\mathrm{g} / \mathrm{d}$} & Young & $581^{\mathrm{A}}$ & $767^{\mathrm{B}}$ & $674^{X}$ \\
\hline & Mature & 872 & 943 & $908^{\mathrm{Y}}$ \\
\hline \multirow[t]{2}{*}{ Dry matter intake, $\%$ BW } & Young & 3.86 & 4.05 & $3.96^{\mathrm{Y}}$ \\
\hline & Mature & 3.48 & 3.57 & $3.53^{\mathrm{X}}$ \\
\hline \multirow[t]{2}{*}{ Dry matter digestibility, $\%$} & Young & $66.5^{\mathrm{A}}$ & $71.1^{\mathrm{B}}$ & 68.8 \\
\hline & Mature & $64^{\mathrm{A}}$ & $73^{\mathrm{B}}$ & 68.5 \\
\hline \multirow[t]{2}{*}{ Digestible dry matter intake, $\mathrm{g} / \mathrm{d}$} & Young & $386^{\mathrm{A}}$ & $545^{\mathrm{B}}$ & $465^{\mathrm{X}}$ \\
\hline & Mature & $557^{\mathrm{a}}$ & $688^{\mathrm{b}}$ & $623^{Y}$ \\
\hline \multirow[t]{2}{*}{ Body weight gain, g/d } & Young & $55.8^{\mathrm{A}}$ & $91.5^{\mathrm{B}}$ & 80 \\
\hline & Mature & $61.6^{\mathrm{A}}$ & $98.4^{\mathrm{B}}$ & 73.7 \\
\hline \multirow[t]{2}{*}{ Feed conversion ratio } & Young & $10.5^{\mathrm{B}}$ & $8.40^{\mathrm{A}}$ & $9.44^{\mathrm{X}}$ \\
\hline & Mature & 14.8 & 9.78 & $12.3^{\mathrm{Y}}$ \\
\hline \multirow[t]{2}{*}{ Carcass weight gain, g/d } & Young & $24.1^{\mathrm{a}}$ & $43.7^{\mathrm{b}}$ & 33.9 \\
\hline & Mature & $22.5^{\mathrm{A}}$ & $44.9^{\mathrm{B}}$ & 33.7 \\
\hline \multirow[t]{2}{*}{ Meat weight gain, g/d } & Young & $15.8^{\mathrm{a}}$ & $29.1^{\mathrm{b}}$ & 22.4 \\
\hline & Mature & $15.2^{\mathrm{A}}$ & $30.4^{\mathrm{B}}$ & 22.8 \\
\hline
\end{tabular}

\footnotetext{
${ }_{a, b ; x, y}$ Means in the same row or column with different superscripts differ $(\mathrm{P}<0.05)$
}

$\mathrm{A}, \mathrm{B} ; \mathrm{X}, \mathrm{Y}$ Means in the same row or column with different superscripts $\operatorname{differ}(\mathrm{P}<0.01)$ 
feed as well as the mature goat did. The result of this study was in agreement with the finding of Prima et al. (2018) that digesting ability of the lamb aged 4 months was similar to that of the ram aged 12 months.

Dry matter digestibility of diet G3C7 was significantly higher $(\mathrm{P}<0.05)$ than that of diet G7C3 (Table 2), both in the young and the mature goats. This was attributed to the fact that diet $\mathrm{G} 3 \mathrm{C} 7$ had lower crude fiber (CF) and higher crude protein $(\mathrm{CP})$ content than did diet G7C3. Dietary CF content influences its digestibility; the higher the CF content of the diet the lower the digestibility. The existence of $\mathrm{CF}$ in the diet was accompanied lignin, the higher the CF content the higher the lignin concentration. The existence of lignin compounded other nutrients such as protein, so that it reduces digestibility. On the other hand, the higher CP content in diet $\mathrm{G} 3 \mathrm{C} 7$ led to high microbial protein growth rate and increased the intensity of nutrient digestion in the rumen (Atti et al., 2004; Askar et al. 2016; Tadesse et al., 2016; Dida et al., 2019). Subsequently, nutrient digestion in the intestine increased.

The DDMI $(\mathrm{g} / \mathrm{d})$ of the young goat $(465 \mathrm{~g} / \mathrm{d})$ was significantly lower $(\mathrm{P}<0.01)$ than that of the mature goat $(623 \mathrm{~g} / \mathrm{d})$. This result was attributed to the fact that DMI of the young goat was lower than that of the mature goat, while DM digestibility of the both ages of goat was similar. The result of this study was in agreement with the finding of Prima et al. (2018) that different DMI accompanied by similar DM digestibility resulted in different DDMI.

The DDMI of the goat fed diet G3C7 was higher than that fed G7C3, both in the young $(\mathrm{P}<0.01)$ and in the mature goats $(\mathrm{P}<0.05)$, as presented in Table 2. This could be attributed to the DMI and DM digestibility of diet G3C7 being higher than that of diet G7C3. As discussed above, the amount of DMI and the percentage of DM digestibility influenced the amount of DDMI. Dung et al. (2014) stated that higher concentrate level in feed resulted in higher amount of nutrient that can be digested.

\section{Body Weight, Carcass Weight and Meat Weight Gain}

In spite of the fact that the body weight of the young goat was lighter than that of the mature goat, there was no significant difference $(\mathrm{P}>0.05)$ between the ages of goats in BWG (averaged $76.9 \mathrm{~g} / \mathrm{d}$ ). The non-significant differ- ence was caused by the fact that the young goat was in exponential growing stage, while the growth rate of mature goat was starting to decline. Diet G3C7 resulted in a significantly higher BWG $(\mathrm{P}<0.01)$ than did diet $\mathrm{G} 7 \mathrm{C} 3$, both in the young and mature goats (Table 2). This was attributed to the higher DMI, DM digestibility and DDMI of diet G3C7 being higher than that of its counterpart. The similar growth rate between the two ages of goat, along with lower DMI of young goat, resulted in a significantly lower FCR $(\mathrm{P}<0.01)$ in the young goat as compared to that in the mature goat (Table 2). The lower FCR in young goat than mature goat caused by the young goat consumed less DMI but have higher BWG than mature goat.

The FCR of diet G3C7 was significantly lower $(\mathrm{P}<0.01)$ than that of diet $\mathrm{G} 7 \mathrm{C} 3$ in the young goat (Table 2). This result indicated that improving feeding quality by including more concentrate in the diet improved FCR in Kejobong young goats. However, there was no significant difference $(\mathrm{P}>0.05)$ in FCR between the two diets in the mature goat. The young goat was in the accelerated growth phase, so that it had high metabolism rate and metabolize nutrients rapidly. This caused the difference of feed digestibility to result in high difference of nutrients utilization. On the other hand, the non-significant difference between the two diets in the mature goat was due to the low metabolism rate low growth rate of the mature goat, resulting in low utilization of nutrients, so that the difference in digestibility between the diets did not significantly affect the efficiency of nutrient utilization in the body. This result was in agreement with the study of Haddad (2005) who found that $70 \%$ concentrate feeding in the combination with grass decreased FCR value by 2.2 points compared to the diet with $40 \%$ concentrate.

There was no significant difference $(\mathrm{P}>0.05)$ between the young and the mature goats in CWG and MWG (averaged 33.8 and $22.6 \mathrm{~g} / \mathrm{d}$, respectively). On the other hand, diet $\mathrm{G} 3 \mathrm{C} 7$ resulted in higher CWG and MWG than diet G7C3 (Table $2)$, both in the young goat $(\mathrm{P}<0.05)$ and in the mature goat $(\mathrm{P}<0.01)$. These were attributed to the fact that BWG of the goats fed diet G3C7 was higher than that diet G7C3. The carcass and meat production are the functions of body weight; carcass and meat weight increase with body weight of the animal.

Diet $\mathrm{G} 3 \mathrm{C} 7$ resulted in higher $\mathrm{CWG}$ and MWG than diet $\mathrm{G} 7 \mathrm{C} 3$ in the young goat $(\mathrm{P}<0.05)$ 
Table 3. The effect of different age and feed quality on methane emissions and methane emissions per unit product

\begin{tabular}{|c|c|c|c|c|}
\hline \multirow[t]{2}{*}{ Parameter } & \multirow[t]{2}{*}{ Age of goat } & \multicolumn{2}{|c|}{ Diet } & \multirow[t]{2}{*}{ Age average } \\
\hline & & G7C3 & G3C7 & \\
\hline \multirow[t]{2}{*}{$\mathrm{CH}_{4}, \mathrm{~g} / \mathrm{d}$} & Young & 21.8 & 26.1 & $24^{\mathrm{X}}$ \\
\hline & Mature & 32.1 & 34.4 & $33.3^{Y}$ \\
\hline \multirow[t]{2}{*}{$\mathrm{CH}_{4} \mathrm{~g} / \mathrm{kg} \mathrm{DMI}$} & Young & 32.4 & 31.2 & 31.8 \\
\hline & Mature & 33.6 & 33.4 & 33.5 \\
\hline \multirow[t]{2}{*}{$\mathrm{CH}_{4} \mathrm{~g} / \mathrm{g} \mathrm{BWG}$} & Young & $0.40^{\mathrm{b}}$ & $0.28^{\mathrm{a}}$ & $0.34^{\mathrm{X}}$ \\
\hline & Mature & $0.53^{\mathrm{B}}$ & $0.36^{\mathrm{A}}$ & $0.45^{\mathrm{Y}}$ \\
\hline \multirow[t]{2}{*}{$\mathrm{CH}_{4} \mathrm{~g} / \mathrm{g} \mathrm{CWG}$} & Young & $0.93^{\mathrm{B}}$ & $0.60^{\mathrm{A}}$ & $0.77^{\mathrm{x}}$ \\
\hline & Mature & $1.47^{\mathrm{b}}$ & $0.79^{\mathrm{a}}$ & $1.13^{\mathrm{y}}$ \\
\hline \multirow[t]{2}{*}{$\mathrm{CH}_{4} \mathrm{~g} / \mathrm{g} \mathrm{MWG}$} & Young & $1.42^{b}$ & $0.89^{\mathrm{a}}$ & $1.16^{\mathrm{x}}$ \\
\hline & Mature & $2.19^{\mathrm{b}}$ & $1.16^{\mathrm{a}}$ & $1.68^{\mathrm{y}}$ \\
\hline
\end{tabular}

and in the mature goat $(\mathrm{P}<0.01)$, as presented in Table 2. This result was attributed to the effect of higher concentrate inclusion in the diet G3C7. Having higher DDMI, diet G3C7 supplied more amounts of nutrients available for production than diet G7C3. This study confirmed the finding of Brand et al. (2019), Brand et al. (2017), and Abubakr et al. (2013) that diets with high feed quality had higher nutrients digestibility (\%), causing more nutrients to be absorbed, and support higher BWG.

\section{Methane Emission and Its Relative to Ani- mal's Production}

The methane emission in the young goat a significantly lower $(\mathrm{P}<0.05)$ than that in the mature goat (Table 3 ). This may be attributed to DMI of the young goat being lower than that of the mature goat (Table2). DMI is highly correlated to $\mathrm{CH}_{4}$ production, and it can be used as a single variable to predict $\mathrm{CH}_{4}$ emission (Nkrumah et al., 2006, Ellis et al., 2007; Shibata and Terada, 2010).

The methane emission from the goats fed G7C3 and G3C7 was not significantly different $(\mathrm{P}>0.05)$ in both ages (averaged $28.6 \mathrm{~g} \mathrm{CH} 4 / \mathrm{d}$ ). There was no significant difference $(\mathrm{P}>0.05)$ either between the ages of goat or between diets in methane emission per unit DMI (averaged $32.65 \mathrm{~g} / \mathrm{kg}$ DMI; see Table 3). This indicated that the fermentation rates of the diets were similar due to similar passage rate resulted of pelleted form that were ground in similar ground size (Ramirez Ramirez et al., 2016; Huhtanen et al., 2016).

There was significant difference between the young and the mature goats in methane emission per BWG $(\mathrm{P}<0.01), \mathrm{CWG}$ and MWG $(\mathrm{P}<0.01)$ (Table 3). The methane emissions per unit BWG, CWG and MWG in the young goat were lower than those in the mature goat. This was because the growth rate of young goats was in accelerated phase, so that it produced $\mathrm{BWG}, \mathrm{CWG}$ and MWG as much as the mature goats, while DMI of the young goat was lower, resulting a lower methane emission, than that in the mature goat. Therefore, in term of methane emission, the young goat was more environmentally cost effective than the mature goats. It was parallel with the findings of Porsavathdy et al. (2017) that the higher productivity can reduce methane emission.

The goat fed diet G3C7 had significantly lower methane emission per unit of BWG $(\mathrm{P}<0.01)$, 
Table 3. The effect of different age and feed quality on methane emissions and methane emissions per unit product

\begin{tabular}{|c|c|c|c|c|}
\hline \multirow{2}{*}{ Parameters } & \multirow{2}{*}{ Age of goat } & \multicolumn{2}{|c|}{ Diet } & \multirow{2}{*}{ Age average } \\
\hline & & G7C3 & G3C7 & \\
\hline \multirow[t]{2}{*}{$\mathrm{CH} 4, \mathrm{~g} / \mathrm{d}$} & Young & 21.8 & 26.1 & $24^{\mathrm{X}}$ \\
\hline & Mature & 32.1 & 34.4 & $33.3^{Y}$ \\
\hline \multirow[t]{2}{*}{$\mathrm{CH} 4 \mathrm{~g} / \mathrm{kg}$ DMI } & Young & 32.4 & 31.2 & 31.8 \\
\hline & Mature & 33.6 & 33.4 & 33.5 \\
\hline \multirow[t]{2}{*}{$\mathrm{CH} 4 \mathrm{~g} / \mathrm{g} \mathrm{BWG}$} & Young & $0.40^{\mathrm{b}}$ & $0.28^{\mathrm{a}}$ & $0.34^{\mathrm{X}}$ \\
\hline & Mature & $0.53^{\mathrm{B}}$ & $0.36^{\mathrm{A}}$ & $0.45^{\mathrm{Y}}$ \\
\hline \multirow[t]{2}{*}{$\mathrm{CH} 4 \mathrm{~g} / \mathrm{g} \mathrm{CWG}$} & Young & $0.93^{\mathrm{B}}$ & $0.60^{\mathrm{A}}$ & $0.77^{x}$ \\
\hline & Mature & $1.47^{\mathrm{b}}$ & $0.79^{\mathrm{a}}$ & $1.13^{y}$ \\
\hline \multirow[t]{2}{*}{$\mathrm{CH} 4 \mathrm{~g} / \mathrm{g}$ MWG } & Young & $1.42^{b}$ & $0.89^{\mathrm{a}}$ & $1.16^{\mathrm{x}}$ \\
\hline & Mature & $2.19^{b}$ & $1.16^{\mathrm{a}}$ & $1.68^{\mathrm{y}}$ \\
\hline
\end{tabular}

$\mathrm{a,b} ; \mathrm{x,y}$ Means in the same row or column with different superscripts differ $(\mathrm{P}<0.05)$

$\mathrm{A}, \mathrm{B} ; \mathrm{X}, \mathrm{Y}$ Means in the same row or column with different superscripts $\operatorname{differ}(\mathrm{P}<0.01)$

per unit of CWG $(\mathrm{P}<0.05)$, and per unit of MWG $(\mathrm{P}<0.05)$, both in the young and the mature goats (Table 3). The low methane emission per unit of BWG, CWG and MWG in the goat fed diet $\mathrm{G} 3 \mathrm{C} 7$ young goat were due to the diet $\mathrm{G} 3 \mathrm{C} 7 \mathrm{had}$ higher digestibility, which resulted in higher amount of nutrients available for production, compared to diet G7C3. This, in turn, led the methane emission per unit product of the goat fed diet G3C7 to be lower than that fed diet G7C3. This result was in agreement with the statement of Waghorn and Hegarty (2011) and Marino et al. (2016) that high feed quality can reduce methane emission per unit of product.

The results of this study were then used to compare the conventional fattening system (that is practically done in the rural area; using mature animal and low quality of feed) to early fattening system (using young animal and high quality of feed) based on the approach of Life Cycle Assessment (LCA) concept. The diet used in conventional fattening program was $\mathrm{G} 7 \mathrm{C} 3$ (represent low quality diet), while the diet in early fattening program used G3C7 (represent high quality diet). The conventional fattening program required 420 days to reach a slaughter body weight with total methane emission about 13,482 $\mathrm{g} /$ head. In comparison, the early fattening program required 330 days to reach slaughter body weight with total methane emissions of about $8,613 \mathrm{~g}$ methane per head. Therefore, the early fattening system could save 3 months for providing the stocker animals for fattening may contribute an economically benefit through faster rapid capital turnover, and reduced methane production by $4,869 \mathrm{~g}$ per head, or equal to $36.1 \%$.

\section{CONCLUSION}

The early fattening program of the young Kejobong goat using high quality feed is less time consuming and more environmentally friendly, in comparison to the conventional fattening program. The early fattening program could save 3 months rearing time and increase benefit through rapid capital turnover and reduce methane emission by $4,869 \mathrm{~g}$ per head (36.1\%), in comparison to the conventional fattening program.

\section{ACKNOWLEDGMENTS}

The authors are very grateful to the member of Potongmania-Johar Research Team for their technical assistance, patience and love during the 
experiment and to Dr. Sugiharto for proofreading the manuscript.

\section{REFERENCES}

Abubakr, A. R., A. R. Alimon, H. Yaakub, N. Abdullah and M. Ivan. 2013. Growth, nitrogen metabolism and carcass composition of goats fed palm oil by-products. Small Rumin. Res. 112: 91-96.

Adler, A. A., G. J. Doole, A. J. Romera and P. C. Beukes. 2013. Cost-effective mitigation of greenhouse gas emissions from different dairy systems in the Waikato region of New Zealand. J. Environ. Manage. 131: 33-43.

Ali, A., S. H. Raza and A. Ghaffar. 1990. Eating and rumination in relation to age of lactating buffalo. Appl. Anim. Behav. Sci. 28: 273279.

Askar, A. R., M. S. Nassar, H. S. Badawy, E. Y. Eid, J. A. Guada and M. F. A. Farid. 2016. Recovered energy and efficiency of digestion in sheep and goats fed Atriplex nummularia compared to alfafa hay. Livest. Sci. 194: 1-6.

Atti, N., H. Rouissi and M. Mahouachi. 2004. The effect of dietary crude protein level on growth, carcass and meat composition of male goat kids in Tunisia. Small Rumin. Res. 54: 89-97.

Belanche, A., J. M. Palma-Hidalgo, I. Nejjam, E. Jimenez, A. I. Martin-Gracia and D. R. Yanez -Ruiz. 2020. Innoculation with rumen fluid in early life as a strategy to optimize the weaning process in intensive dairy goat systems. J. Dairy Sci. 103: 5047-5060.

Brand, T. S., D. A. Van Der Merwe, E. Swart, and L. C. Hoffman. 2017. Comparing the effect of age and dietary energy content on feedlot performance of Boer goats. Small Rumin. Res. 157: 40-46.

Brand, T. S., D. A. Van Der Merwe, E. Swart and L. C. Hoffman. 2019. The effect of finishing periodand dietary energy content on the carcass characteristics of Boer goats. Small Rumin. Res. 174: 110-117.

Brouwer, E. 1965. Report of sub committee on constants and factors. Eaap Publication No 11. Academic Press. London.

Chandramoni, X. X., S. B. Jadhao, C. M. Tiwari and M. Y. Khan. 1999. Carbon and nitrogen balance studies in Muzaffarnagari sheep fed diets varying in roughage and concentrate ratio. Small Rumin. Res. 31: 221-227.
Darcan, N. K. and N. Silanikove. 2017. The adventages of goats for future adaptation to climate change: A conceptual overview. Small Rumin. Res. 163:34-38.

Dida, M. F., K. Y. G. Sahay and D. Geleti. 2019. Effect of feeding different proportions of pigeon pea (Cajanus cajan) and neem (Azadirachta indica) leaves on feed intake, digestibility, body weight gain and carcass characteristics of goats. Vet. Anim. Sci. 8: 100079.

Dung, D. V., W. Shang dan W. Yao. 2014. Effect of crude protein levels in concentrate and concentrate levels in diet on in vitro fermentation. Asian Australas. J. Anim. Sci. 27 (6): 797-805.

EPA (Environmental Protection Agency). 2005. Opportunities to Reduce Anthropogenic Methane Emission in the United States. EPA. Washington DC Publication. 430-R93-012.

Ellis J. L., E. Kebreab, N. E. Odongo, B. W. McBride, E. K. Okine, and J. France. 2007. Prediction of Methane Production from Dairy and Beef Cattle. J. Dairy Sci. 90:3456-3467.

FAO (Food and Agriculture Organization of the United Nations). 2009. Global agriculture towards 2050. High Level Expert Forum Issues Paper. FAO. Rome.

Fernandez, C., I. P. Baena, J. V. Martin, J. L. Palomares, J. J. Ripoll and J. V. Segarra. 2018. Use of orange leaves as a replacement for alfalfa in energy and nitrogen partitioning, methane emissions and milk performance of Murciano-Granadina goats. Anim. Feed Sci. Technol. 247: 103-111.

Gerber, P., A. Hristov, B. Henderson, H. Makkar, J. Oh, C. Lee, R. Meinen, F. Montes, T. Ott and J. Firkins. 2013. Technical options for the mitigation of direct methane and nitrous oxide emissions from livestock: a review. Greenhouse Gases \& Animal Agriculture Conference. 7: 220-234.

Gomez, K. A. and A. A. Gomez. 1984. Statistical Procedures for Agricultural Research. $2^{\text {nd- }}$ ed. John Wiley and Sons. New York.

Haddad, S. G. 2005. Effect of dietary forage:concentrate ratio on growth performance and carcass characteristics of growing Baladi kids. Small Rumin. Res. 57: 43-49.

Huhtanen, P., M. Ramin and E. H. CabezasGarcia. 2016. Effects of ruminal digesta retention time on methane emissions: a modelling approach. Anim. Prod. Sci. 56: 501-506

Jiao, H., T. Yan, D. A. Wills, A. F. Carson and 
D. A. McDowell. 2014. Development of prediction models for quantification of total methane emission from enteric fermentation of young Holstein cattle at various age. Agric. Ecosyst. Environ. 183: 160-166.

Kawashima, T, W. Sumamal, F. Terada, and M. Shibata. 2001. Respiration trial system using ventilated flow through method with facemask. JJIRCAS Journal. 9: 53-74.

Kearl, L C 1982 Nutrient Requirements of Ruminant in Developing Countries International Feedstuffs Institute (Utah Agricultural Experiment Statio- Utah State University- LoganUtah- USA).

LEAP 2014 Greenhouse gas emissions and fossil energy demand from 2 small ruminant supply chains: guidelines for quantification. In: Livestock Environmental Assessment 3 and Performance Partnership. FAO. Rome. Italy.

Lestari, D. A., E. Purbowati, S. Sutopo and E. Kurnianto. 2018. Phylogenetical relationships between Kejobong goat and other goats based on Mt- DNA D-loop sequence analysis. Trop. Anim. Sci. J. 41(2): 85-93.

Makuvaro, V., S. Walker, T. P. Masere and J. Dimes. 2018. Smallholder farmer perceived effects of climate change on agricultural productivity and adaptation strategies. J. Arid Environ. 152: 75-82.

Marino, R., A. S. Atzori, M. D'Andrea, G. Iovane, M. Trabalza-Marinucci and L. Rinaldi. 2016. Review article; Climate change: Production performance, health issues, greenhouse gas emissions and mitigation strategies in sheep and goat farming. Small Rumin. Res. 135: 50-59.

Nardone, A., A. Ronchi, B. Lacetera, N. Ranieri and U. Bernabucci. 2010. Effects of climate changes on animal production and sustainability of livestock systems. Livest. Sci. 130: 5769.

Nkrumah, J. D., E. K. Okine, G. W. Mathison, K. Schmid, C. Li, J. A. Basarab, M. A. Price, Z. Wang, and S. S. Moore. 2006. Relationships of feedlot feed efficiency, performance, and feeding behaviour with metabolic rate, methane production, and energy partitioning in beef cattle. J. Anim. Sci. 84:145-153.

O'Mara, F. P. 2012. The role of grasslands in food security and climate change. Review: part of a highlight on breeding strategies for forage and grass improvement. Anna. Bot. 110: 1263-1270.

Opio, C., P. Gerber, A. Mottet, A. Falcucci, G.
Tempio, M. MacLeod, T. Vellinga, B. Henderson and H. Steinfeld. 2013. Greenhouse Gas Emissions from Ruminant Supply Chains-A Global Life Cycle Assessment. FAO. Rome.

Porsavathdy, P., H. Q. Do and T. R. Preston. 2017. Growth rate and feed conversion were improved, and emissions of methane reduced, when goats fed a basal diet of pigeon wood foliage (Trema orientalis) were supplemented with sun-dried cassava foliage (Manihot esculenta, Crantz) or water spinach (Ipomoea aquatica). Livest. Res. Rural Dev. 29 (4).

Prima, A., E. Purbowati, E. Rianto and A. Purnomoadi. 2019. Study on early fattening in sheep as a strategy to reduce nitrogen emissions. IOP Conf. Series: Earth and Environmental Science. 247.

Prima. A., E. Rianto, E. Purbowati and A. Purnomoadi. 2018. Indirect evaluation of digestive tract function on male lambs and ram based on feed digestibility and eating behavior. J. Indones. Trop. Anim. Agric. 43 (2): 124 -130 .

Purnomoadi, A. 2018. Early fattening lamb could mitigate methane production-an example of climate smart livestock farming system in Indonesia. IOP Conf. Series: Earth and Environmental Science. 119.

Ramirez Ramirez. H. A., K. J. Harvatine, and P. J. Kononoff. 2016. Forage particle size and fat intake affect rumen passage, the fatty acid profile of milk, and milk fat production in dairy cows consuming dried distillers grains with solubles. J. Dairy Sci. 99:392-398.

Shibata, M and F. Terada. 2010. Factors affecting methane production and mitigation in ruminants. Anim. Sci. J. 81: 2-10.

Tadesse, D., M. Urge, G. Animut and Y. Mekasha. 2016. Growth and carcass characteristics of three Ethiopian indigenous goats fed concentrate at different supplementation levels. Springer Plus. 5. 414.

Teklebrhan, T., R. Wang, M. Wang, J. N. Wen, L. W. Tan, X. M. Zhang, Z. Y. Ma and Z. L. Tan. 2019. Effect of dietary corn gluten inclusion on rumen fermentation, microbiota and methane emissions in goats. Anim. Feed Sci. Technol. 259:114314.

Tsiplakou, E., L. Hadjigeorgiou, K. Sotirakoglou and G. Zervas. 2011. Differences in mean retention time of sheep and goats under controlled feeding practices. Small Rumin. Res. 95: 48-53. 
UN (United Nations). 2015. World Population Propects. United Nations Departement of Economic and Social Affairs. https:// population.un.org/wpp/Publication/Files/ WWP2015 DataBooklet.pdf

Waghorn, G. C. and R. S. Hegarty. 2011. Lowering ruminant methane emissions through improved feed conversion efficiency G.C. Waghorn, and R.S. Hegarty. Anim. Feed Sci. Technol. 166: 291-301.

Wang, M., R. Wang, T. Y. Xie, P. H. Janssen, X. Z. Sun, K. A. Beauchemin, Z. L. Tan and M. Gao. 2016. Shifts in rumen fermentation and microbiota are associated with dissolved ruminal hydrogen concentrations in lactating dairy cows fed different types of carbohydrates. The J. Nutr. 146 (9): 1714-1721.
Webb, J., E. Audsley, A. Williams, K. Pearn and J. Chatterton. 2014. Can UK livestock production be configured to maintain production while meeting targets to reduce emissions of greenhouse gases and ammonia? J. Clean. Prod. 83. 204-211.

Wyngaard, J. D. V. V., R. Meeske and L. J. Erasmus. 2018. Effect of concentrate feeding level on methane emissions, production performance and rumen fermentation of Jersey cows grazing ryegrass pasture during spring. Anim. Feed Sci. Technol. 241: 121-132.

Zucalli, M., D. Lovarelli, S. Celozzi, J. Bacenetti, A. Sandrucci and L. Bava. 2020 Management options to reduce the environmental impact of dairy goat milk Production. Livest Sci. 231: 103888. 